\title{
Effects of BRI strategy on Mediterranean shipping transport
}

\author{
Claudio Ferrari ${ }^{1}$ and Alessio $\mathrm{Tei}^{1,2^{*}}$ (i)
}

\author{
* Correspondence: alessio.tei@ncl.ac. \\ uk; alessio.tei@unige.it \\ ${ }^{1}$ Department of Economics and \\ Business, University of Genoa, Via \\ Vivaldi 5, 16126 Genova, Italy \\ ${ }^{2}$ School of Engineering, Newcastle \\ University, Queen Victoria Road, \\ Newcastle upon Tyne NE17RU, UK
}

\begin{abstract}
In 2013 Chinese government unveiled one of the biggest transport plan schemes worldwide: the One Belt One Road (OBOR) strategy, now called the Belt and Road Initiative (BRI). This scheme includes the development of a group of specific transport and logistics corridors that encompass three different continents (i.e. Asia, Africa, and Europe) with both land and maritime corridors. Both these planned interventions are expected to greatly impact on the maritime transport between Far East and Northern Europe through new port investments (e.g. Piraeus, the proposed Venice container offshore terminal) and providing rail alternatives (e.g. BeijingHamburg rail service) that could impact on the geography of international trades. These modifications of current transport patterns might drastically change the overall organisation of the shipping services in the Mediterranean, increasing competition of transport alternatives (e.g. rail vs road; rail vs sea) and promoting the nodes included in the BRI. Thus, the current study aims at discussing effects of BRI on current maritime patterns with a specific focus on the effects into port competition within the Mediterranean area.
\end{abstract}

Keywords: Belt and road initiatives, Logistics corridors, Port competition, Intermodal transport, Transport investments

\section{Introduction}

Over the centuries, maritime transport has often been promoted as the only transport mean capable of competing for large volumes of traffics in long distance routes (e.g. Stopford, 2009). Together with this peculiar characteristic, all main operators were used to compete freely and independently in order to attract customers and serve cargo-owners worldwide. The large diffusion of container shipping - favouring vertical and horizontal integration strategies - drastically changed these traditional elements of the shipping business, with the need for aggregations that became a paramount need for most operators, as for the case of Merges and Acquisitions (M\&A) and the formation of strategic alliances (Midoro and Pitto 2000). The wave of consolidations - that started around the end of the ' 90 s and it is currently still ongoing - dramatically changed the shipping market. Even if in container liner shipping this trend seems to have impacted the most, with the main 3 alliances controlling more than $90 \%$ of main routes, according to Drewry (2018), other liner markets (e.g. short sea shipping) and

(c) The Author(s). 2020 Open Access This article is licensed under a Creative Commons Attribution 4.0 International License, which permits use, sharing, adaptation, distribution and reproduction in any medium or format, as long as you give appropriate credit to the original author(s) and the source, provide a link to the Creative Commons licence, and indicate if changes were made. The images or other third party material in this article are included in the article's Creative Commons licence, unless indicated otherwise in a credit line to the material. If material is not included in the article's Creative Commons licence and your intended use is not permitted by statutory regulation or exceeds the permitted use, you will need to obtain permission directly from the copyright holder. To view a copy of this licence, visit http://creativecommons.org/licenses/by/4.0/. 
bulk shipping operators (e.g. with the development of pool system and other joint investment programs) have also experienced similar trends. The related market concentration on the sea side pushed several companies to compete also at land side, with vertical integration strategies that often involve not only terminal operations but land transport and logistics services as well (e.g. Notteboom et al. 2017). The competitive advantage has been then moved from the port-to-port services to the door-to-door intermodal transport, pushing national authorities to provide subsequent infrastructure and regulatory improvements (e.g. rail and road connections with ports, automated gates, e-documents, single window), in order to increase the possibility to promote such kind of integrated transport solutions. Thus, the need for integrated regional transportation systems generated the need for integrated transport policies that increased regional accessibility and allowed operators to improve their integrated networks (e.g. $\mathrm{Ng}$ et al. 2018). In the European Union, Trans-European Network is an example of such policy, with the selection of core ports and related major logistics corridors (e.g. Ferrari et al. 2018). Nevertheless, while most of these projects are at regional level, the Belt and Road Initiative, promoted by Chinese government, is currently the only one having a worldwide scope.

In fact, the Belt and Road Initiative (BRI) evokes the development of a modern "Silk Road" connecting China with other major partner countries within and outside Asia (mainly located in either Europe or Africa). Started in 2013 with the label of the "One Belt, One Road" (OBOR) project, this integrated transport strategy has been substantially developed thanks to the financial initiative of Chinese institutions. Starting from 2016 the initiative was opened to the support of international partners, mainly connected to the recently funded Asia Infrastructure Investment Bank: more than 1 trillion USD project value has already been approved (EBRD 2018).

According to Cheng (2016), the huge financial effort promoted by Chinese institutions has several goals but the main one is obviously connected to the promotion of Chinese companies worldwide, granting them a competitive advantage thanks to the investments in strategic infrastructures. Pelagidis and Haralambides (2019) highlighted how "a 10\% improvement in connectivity between countries along the "Maritime Silk Road" [i.e., the part of BRI connected to maritime corridors] would deliver a 3\% decrease in Chinese trade costs which would, in turn, boost China's imports and exports by around $6 \%$ and $9 \%$, respectively".

While several countries highlighted the potential effects on fair competition between local and Chinese companies (e.g. Herrero and $\mathrm{Xu}$ 2017), most of the countries welcomed the new infrastructure investments that might drastically change current transport patterns and logistics. Among the regions that will probably be mostly impacted by the BRI there is the Mediterranean basin that will experience a series of investments in both the port and rail sector together with some special trade and financial agreements. The new logistics corridors might then affect not only the shipping industry in the Mediterranean but also the overall transport industry at European level, as discussed by Yang et al. (2018a) and Costa et al. (2020). Concerning this latter issue, it is quite important to highlight how Europe seems to be central to the BRI development, being the other end of both the "road" and the "belt" (i.e., the improved maritime services and the land alternatives, respectively) of the overall strategy. Moreover, within the BRI development several traditional peripheral and landlocked markets (e.g. Central 




Fig. 1 The research approach (Source: Authors' elaboration)

Asia, part of Eastern and Central Europe) will be finally efficiently connected to main world routes. In particular, Eastern and Central Europe might be served efficiently by both the land and the maritime side of the BRI (Costa et al. 2020). Whoever will be able to perform services exploiting the advantages of these new corridors, will therefore assure an incredible competitive advantage for the near future. While published papers on the BRI (e.g. Wang et al. 2018a, Wang and YAU 2018b; Zeng et al. 2018) are focused on specific transport projects or on the optimization of transport patterns, the present paper will then discuss potential effects of current and foreseen investment on the Mediterranean shipping market, with a specific focus on the container shipping.

The aim is then to assess if current BRI related investments could positively affect future transport market competitiveness in the Med area and how they can impact on the regional logistics.

The paper is structured as follows. After this first introduction, Section 2 briefly describes the adopted research approach, while Section 3 addresses BRI developments and its goals. Section 4 is then dedicated to the discussion of main transport projects in the Mediterranean area, focusing on how this might affect current shipping and transport solutions. Eventually, Section 5 addresses subsequent policy implications, drawing main conclusions and a reminder for future research.

\section{The research approach}

In order to achieve the research goal a three-phase desktop analysis has been developed, following the triangulation research approach. As shown in Fig. 1, the research has been developed through a literature review, an analysis of media news on potential projects, and then a confrontation with public data from main market operators.

Thus, the first step consisted in a major literature review, using the public database Scopus. ${ }^{1}$ In order to focus on main papers, a structured research has been developed

${ }^{1}$ The database research has been performed during Spring 2019 and it included papers from 2012 onwards. During the development of the research, some more papers have been published and the most relevant ones are used as key reference for the discussion but not included in the formal literature assessment. 
using "One Belt One Road" or "Belt and Road Initiative" as search keywords. 209 and 278 papers have been found, respectively. Most of the papers actually focus on the political and financial issues rather than the transport features.

Given the variety of topics discussed, a further selection has been developed, adding a second search code (i.e. "Transport") to the previous two selections. This operation resulted in a more focused group of researches of 25 and 23 papers, respectively. All these papers (summarized in Table 1) have then been used for better understanding the implications of BRI on the transport network and on the Mediterranean region in particular.

As shown in Table 1, all the papers have been published within the last 4 years and most of them focus either on specific case studies (mainly located in Asia) or on general network issues. These latter aspects are quite important since only a limited number of papers assessed the impacts of BRI projects on European logistics (among the exceptions, Yang et al. 2018a; Nežerenko and Koppel $2017^{2}$ ) and none of them discusses the consequences of BRI in the Mediterranean area. This latter element generates a limited knowledge on the effects of the several projects under discussion on the current market structure. Moreover, the only highly cited papers (i.e. Ferdinand 2016; Fallon 2015) are actually again discussing political implications of the BRI strategy with only few examples of the transport impacts. The abovementioned elements are probably connected to the novelty of the investments in the European continent and with the nature of the Belt and Road Initiative as well. For this reason, the media assessment and the industry analysis have been developed, in order to include latest investments in the assessment of the BRI consequences on competition on the Mediterranean market.

Table 1 shows different interesting facts concerning the papers on BRI currently published: almost $40 \%$ of the papers do not discuss as main research focus any transport related issue but only use transport as key example for developing further considerations. These papers are mainly socio-politics related and they are interested in discussing the evolution of BRI rather than transportation aspects. Moreover, another $30 \%$ of the papers focus on general logistics aspects, only partially related with the maritime industry: this latter sector seems to be marginal - at least until now - in the overall debate on BRI. Despite these considerations, the importance the BRI might have for logistics and maritime industry is highlighted in the journal target of these papers: the studied sources have been published in a variety of different journals (46 different sources) belonging to different subject areas (i.e., business, economics, logistics, maritime studies, political science, law), underlining a wide spread of potential interests. Only six journals accounted for more than one paper published on either BRI or OBOR: the most relevant source is Maritime Policy and Management (with 7\% of the overall consulted sources, thanks to a special issue of the journal dedicated to the BRI) followed by Transportation Research Part D (4\%). Thus, despite the main focus of the studies is coming more from a political perspective, transportation journals recognise the primary interest that BRI might generate for the future of logistics and transport industries.

${ }^{2}$ In late 2019 and early 2020, a few more papers assessed the impact of BRI on the European logistics, among which: Costa et al. (2020) and Palagidis and Haralambides (2019). 
Table 1 Assessed papers

\begin{tabular}{|c|c|c|c|c|c|}
\hline Area of study & Main discussed topics & $\begin{array}{l}\text { Mention of } \\
\text { "Europe" }\end{array}$ & $\begin{array}{l}\text { Papers } \\
\text { with } \\
\text { "BRI" }\end{array}$ & $\begin{array}{l}\text { Papers } \\
\text { with } \\
\text { "OBOR" }\end{array}$ & Source \\
\hline $\begin{array}{l}\text { General } \\
\text { Logistics }\end{array}$ & $\begin{array}{l}\text { Improvements on current } \\
\text { logistics services or } \\
\text { intermodal transport along } \\
\text { parts of the BRI. Most of the } \\
\text { paper actually discuss } \\
\text { specific case studies or } \\
\text { compare current situation } \\
\text { to possible future scenarios. }\end{array}$ & 4 & 10 & 8 & $\begin{array}{l}\text { Sheu and Kundu 2018; Kuzmicz } \\
\text { and Pesch 2018; Liu et al. 2018; } \\
\text { Choi and Chen 2018; Nazarko } \\
\text { et al. 2017; Xu et al. 2017; } \\
\text { Nežerenko and Koppel 2017; } \\
\text { Lim et al. 2017; Wang and } \\
\text { YAU 2018; Chhetri et al. 2018; } \\
\text { Hou 2018; Sterling and Liu 2018; } \\
\text { Zhang 2018; Ji and Sun 2017; } \\
\text { Zhang 2016a; Lau et al. 2018; } \\
\text { Bekturganov and Bolaev 2017 }\end{array}$ \\
\hline $\begin{array}{l}\text { Maritime Silk } \\
\text { Road - Shipping }\end{array}$ & $\begin{array}{l}\text { Most of the studies discuss } \\
\text { potential optimization } \\
\text { processes (e.g. routing) } \\
\text { connected with certain BRI } \\
\text { investments (e.g. Kra Canal, } \\
\text { integration of services). Some } \\
\text { of the recent works focus on } \\
\text { the possibility to consider } \\
\text { services offered within the } \\
\text { BRI as complimentary } \\
\text { among each rather (i.e. Rail } \\
+ \text { Ship) rather than in } \\
\text { competition. }\end{array}$ & 3 & 5 & 6 & $\begin{array}{l}\text { Yang et al. 2018b; Heng and } \\
\text { Yip 2018; To and Lee 2018; } \\
\text { Saha 2018; Hou 2017a; } \\
\text { Hou 2017b; Zeng et al. 2018; } \\
\text { Wang and YAU 2018; } \\
\text { Du et al. 2018; Qiu et al. 2018; } \\
\text { Ding et al. 2018 }\end{array}$ \\
\hline $\begin{array}{l}\text { Not transport } \\
\text { focused }\end{array}$ & $\begin{array}{l}\text { Most of the studies in this } \\
\text { category discuss transport } \\
\text { as part of the overall BRI } \\
\text { strategy but they mainly } \\
\text { focus on other aspects } \\
\text { of BRI, such as Foreign } \\
\text { Direct Investments (FDIs), } \\
\text { local development, legal } \\
\text { issues, and political } \\
\text { consequences. }\end{array}$ & 5 & 12 & 10 & $\begin{array}{l}\text { Yu and Chang 2018; } \\
\text { Rozov 2018; Malle 2017; } \\
\text { Calabrese 2017; Mednikarov } \\
\text { et al. 2017; Sharif and } \\
\text { Hyder 2017; Ferdinand 2016; } \\
\text { Huasheng 2016; Chia 2016; } \\
\text { Mikheev et al. 2015; Dave } \\
\text { and Kobayashi 2018; Napasirth } \\
\text { and Napasirth 2018; Ismailov } \\
\text { and Papava 2018; Li et al. 2018b; } \\
\text { Lávut 2018; Herrero and } \\
\text { Xu 2017; Li et al. 2017; Li and } \\
\text { Schmerer 2017; Weihai 2017; } \\
\text { Suocheng et al. 2017; } \\
\text { Chen 2017; Fallon 2015 }\end{array}$ \\
\hline $\begin{array}{l}\text { Focus on } \\
\text { railway } \\
\text { corridors }\end{array}$ & $\begin{array}{l}\text { Most of the studies focus } \\
\text { on the description and } \\
\text { assessment of new rail } \\
\text { alternatives linked to BRI } \\
\text { development }\end{array}$ & 2 & 3 & 3 & $\begin{array}{l}\text { Li et al. 2018a; Bao 2018; } \\
\text { Lapidus and Misharin 2018; } \\
\text { Jiang et al. 2018; Zhu and } \\
\text { Vadim 2018; Zhang 2016b }\end{array}$ \\
\hline
\end{tabular}

Looking at the geographical scope, only a quarter of the selected sample discusses at least partially - effects of BRI on European regions (of which only 3 papers are within the maritime literature). This fact might be related to the recent stress on the European investments while most of the initial projects have been mainly developed in Asia. Interestingly, no papers are currently specifically addressing African projects, despite the many ideas currently under-development. Eventually, from a development point of view, it is interesting to notice how the two terms OBOR and BRI are currently used with no differences, despite the Chinese government is now pushing through the use of the latter (considered more politically correct and capable of attracting multinational support) rather than the former one that was initially perceived more as a unilateral action. 


\section{The belt and road initiative}

In accordance with Chinese governmental reports and with several papers (e.g. Huang 2016; Cheng 2016), BRI has a plurality of goals that are mainly connected to political and economic issues (e.g. opening of developing markets for Chinese companies, economic cooperation). This plurality of goals made BRI projects being interrelated with a plurality of economic sectors: Fig. 2, for instance, shows the value of contracted BRI projects, underlining how transport investments are just a part of the overall invested value. It is noteworthy that some previous FDIs are now considered part of the BRI strategy even if they have been agreed before the launch of the initiative (i.e. 2013).

Despite the role of many strategic and political reasons in the BRI related decisionmaking process, from a transport perspective, the BRI strategy will increase the connectivity through specific transport investment projects and long-term collaborations between China and several Asian, African, and European partners. Thus, the BRI differs from other transport investment strategies (e.g. the TEN-T) because it is not looking at increasing cohesion among different regions but it focuses on boosting the connectivity of regions that are currently included in selected trade lanes or forming "priority targets" (e.g. Ferrari et al. 2018). In one of the official documents describing the vision of BRI (Huang 2016; Cheng 2016), president Xi, delineated the characteristics of the commercial partners and regions that might be included in such group (i.e. political and economic conditions) even if an official list of countries does not currently exist. Within the description, the need to invest in order to bring long term advantages for the Chinese communities is one of the most stringent criteria. Thus, while often BRI is connected to investment on transport infrastructures, these investments are normally linked to a "foreigner" (from the receiver viewpoint) strategic advantage. Therefore, even if main projects are strictly linked with integrated logistics chains, these should be considered either strategic to Chinese companies or having a substantial industrial link for generating future trade flows. While the scope of the initiative is not only infrastructure related, overall, BRI is mainly developed through land (i.e. both road and rail) and maritime integrated transport corridors, having a variety of specific international projects that aims at connecting different strategic markets or to bypass potential

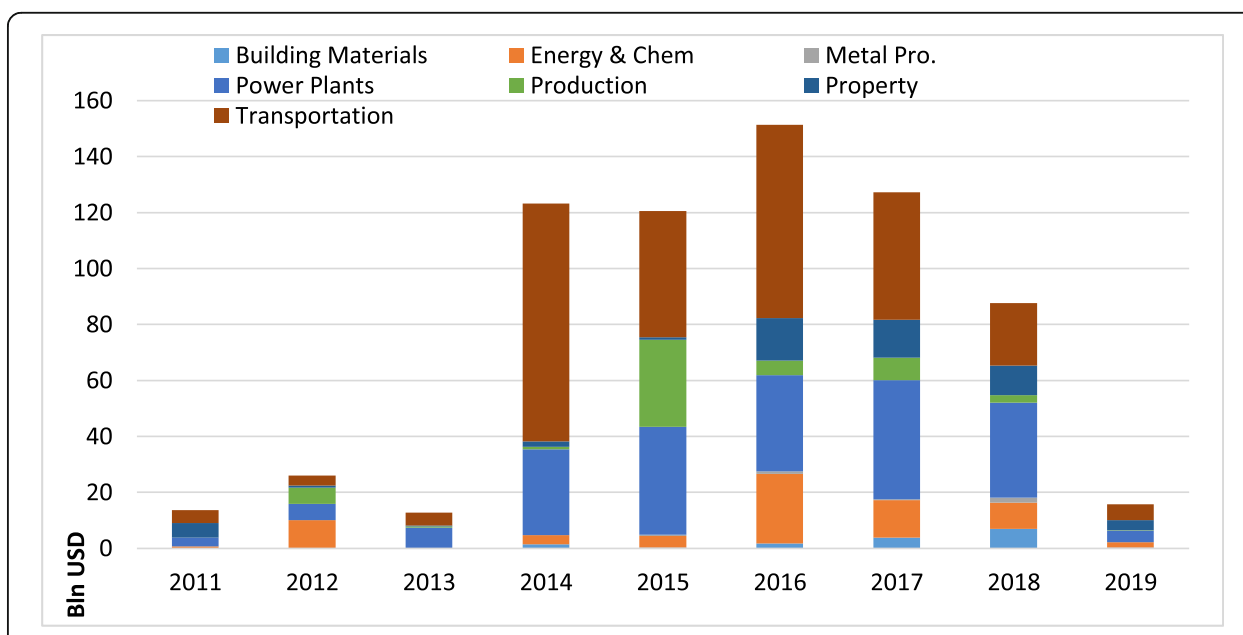

Fig. 2 Contracted projects (Source: Authors' elaboration from Clarkson-SIN data, 2019) 
bottlenecks in the aim of increasing the security of the trade flows (e.g. energy sources, raw materials, traded commodities). An example of such approach might be the proposed investment on the new Kra Canal that aims at bypassing the Malacca straight, making the Far East-Europe trade route faster and avoiding the potential bottleneck represented by the straight.

Given the nature of the initiative, the development of the projects is normally not related to a specific policy or company interventions but it strongly depends on bilateral - and in a few cases multilateral - agreements between Chinese institutions and national authorities. For this latter reason, BRI is a discontinuous and heterogenic strategy that - even if it is based on a single perceived view - it does not normally promote specific transport solutions but general logistics corridors. This is partially aligned with what happens for certain other regional transport planning solutions but the absence of a recognised multinational planner generates the possibility for discontinuous progress (e.g. because of either different regulators/rules or for rising issues in fully recognising competing national interests).

Thus, often BRI is developed through differentiated solutions and ad-hoc investment tools connected to the market conditions characterising the region under investment. This was the case of the massive COSCO investment in the Greek port system during the financial crisis (2012-2016) as well as the foreseen investments in Sri Lanka container hub in 2016-17. Most of the abovementioned solutions are often constructed as a phased privatisation process, with concession agreements or Build-Operate-Transfer (BOT) contracts that might turn to generate fully privatised infrastructures if certain conditions are met (as in the case of Piraeus and most of the Pakistan and Sri Lanka investments).

Some of the abovementioned policies are also linked to new infrastructure solutions, such as the foreseen Kra Canal in Thailand (Zeng et al. 2018) that will help bypassing the Malacca strait reducing shipping time between Europe and Asia of up to 5 days.

From a transport point of view, BRI is based on a multitude of projects within three main pillars: the Intra-Asia corridor (mainly through land infrastructures), Europe-Asia corridors (mainly through maritime investments but also with an improvement of rail connections, especially with South East and Central Asia), and the Asia-Africa corridors (mainly through maritime investment and logistics improvements in African countries). Figure 3 sums up these main logistics corridors.

In relation to the main projects, Table 2 shows the geographic distribution of the main investments. As it is possible to see, while all main world regions are actually included in the BRI strategy, most of the projects are located in either Asia or Africa. Despite this, Eastern European countries managed to attract almost a third of the overall contracted project value, underlining their strategic role within the BRI.

Considering the Asia-Europe part of BRI, it is divided in three distinct sub-groups of projects: the first one is a rail corridor currently in operation that partially uses the Russian rail network, connecting Chinese main production sites with Western European countries. The aim of this first corridor is to improve the competition of the railways for many added value trade flows and it is currently operating low quantity of cargo halving the transportation time between China and Europe. Despite some limited numbers, Yang et al. (2018b) highlighted the high rate of growth of such logistics solution with about 3640 trains organised in 2017 - divided in several rail services - to 


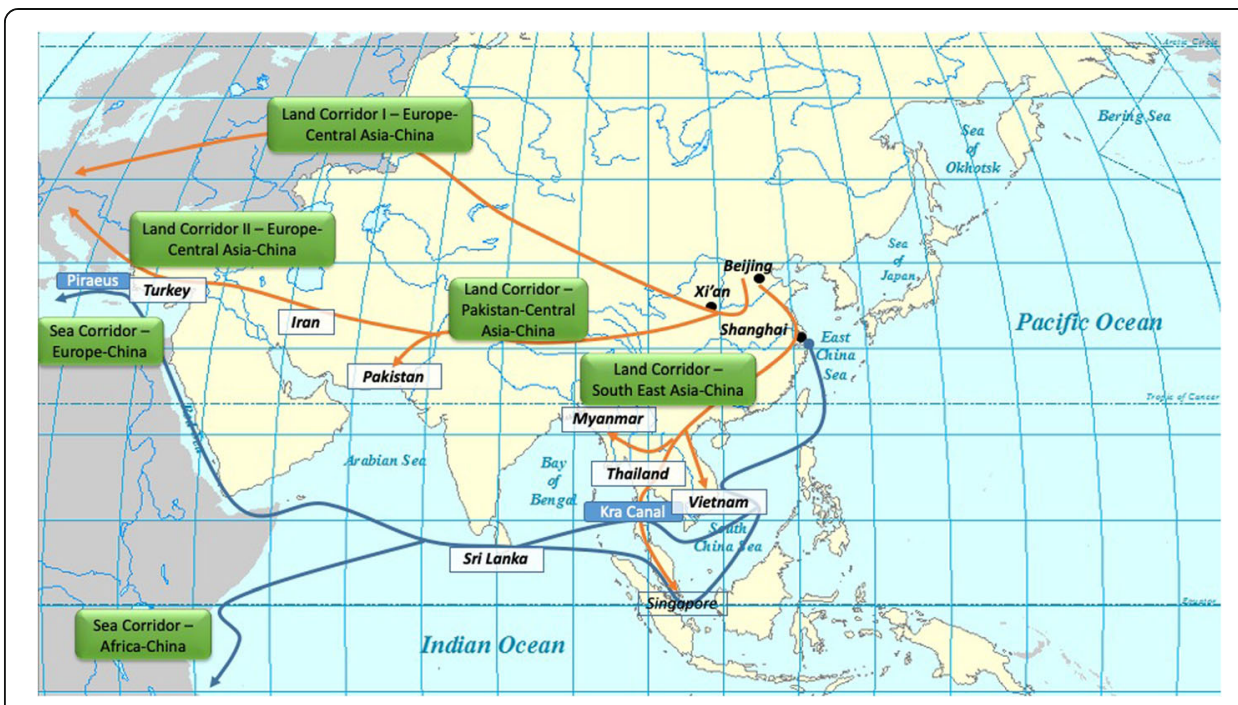

Fig. 3 BRI corridors (Source: Ferrari et al. 2018)

connect Chinese cities with European locations (mainly in Germany and Eastern Europe), against the only 623 trains in 2015 (with only eleven services) and about 11 trains organised in 2011 (Yang et al. 2018a).

The second land corridor, which should pass through Iran and Turkey, is under development and the related international agreements are still to be signed. In principle it should guarantee a competitive road and rail connections among Central Asian countries and both China and Eastern Europe. As mentioned by Costa et al. (2020) and Pelagidis and Haralambides (2019) the possibility provided by such corridor might create a decisive competitive advantage in order to bypass traditional shipping services (i.e., Far East-Europe) in order to serve the fast growing economies located in both Central Asia and Eastern Europe from Asia also creating a new gateway towards Central Europe (i.e., Austria and Germany).

Table 2 ongoing Transport BRI projects

\begin{tabular}{ll}
\hline N. of Projects & \\
Americas & $3 \%$ \\
Africa & $25 \%$ \\
Europe & $9 \%$ \\
East and South-East Asia & $25 \%$ \\
Other Asia & $36 \%$ \\
Others & $1 \%$ \\
Percentage of contracted value & \\
South East Asia & $28 \%$ \\
Southern Asia & $16 \%$ \\
Eastern Europe & $30 \%$ \\
Eastern Africa & $10 \%$ \\
Others & $15 \%$ \\
\hline
\end{tabular}


The third Europe-Asia corridor is the maritime one (i.e. Maritime Silk Road) that will see an intensification of the flows between Chinese ports and European ports with Chinese companies already involved in several investments in transhipment hubs along the main route (such as Sri Lanka and Piraeus, in Greece) in order to acquire a regional competitive advantage in serving local regional traffic. The abovementioned Kra-Canal is also another element included in this part of the strategy.

In respect to other transport strategies, BRI is different not only for its aim but also for the governance and the investment patterns. The governance of different projects is often linked to specific international agreements, thus promoting differentiated solutions that might go from a simple public-private collaboration to a more top-down approach in which the foreign investors (i.e. Chinese companies) control all the construction and management of the project with low involvement of local partners. Within the Europe-Asia corridors, all different solutions have been deployed, with most of the infrastructure given through concession agreements - at least at the beginning, as in the case of Piraeus port - but most of the managerial activities (e.g. promotions of specific logistics and technological services) directly run by private companies.

Another issue is related to the investment pattern that affects every consideration on the BRI strategy and on potential market effects. Given the relative novelty of the BRI (i.e. from 2013 onwards), only few projects have been completed while most of them are either in the construction phase or still in a bargaining phase with the relevant local authorities. Moreover, most of the completed projects are actually pure monetary investments headed to control and/or expand existing infrastructures, as in the case of the port sector in both Asia and Europe. An example is again the port of Piraeus, in which $\mathrm{COSCO}$ (the biggest Chinese shipping operator) decided to invest in the Greek port system well before the BRI started (i.e. in early '00s) through a concession agreement (Psaraftis and Pallis 2012). Nevertheless, the need for privatization after the Greek political turmoil (i.e., after the 2008 financial crisis) - and the consequent starting plan of BRI - facilitated the entrance of COSCO in the Piraeus Port Authority capital. Thanks to this investment, COSCO became the main shareholder (currently holding the $67 \%$ of the capital), making the Greek port the pivotal BRI investment in the Mediterranean basin.

While it is in principle possible to identify the different BRI corridors meant to serve the Europe-Asia trade, the discontinuous nature of the BRI makes most of the projects capable of serving a plurality of solutions and "corridors". For this reason, for instance, Piraeus port is not only connected to the Maritime Silk Road but it will be also connected to the EuroAsia rail link, using rail services as a complementary mean for the new shipping solutions through the expected rail infrastructure connecting Piraeus with Budapest (i.e., the Central European markets).

Despite this latter element, none of the foreseen integrated transport corridors have been actually entirely developed and this limits the possibility to evaluate the economic and social impact of the proposed solutions. For this reason, several authors (e.g. Herrero and Xu 2017; Huang 2016) raised issues on the potential market and economic effects of such investments, given that limited assessments have been developed for most of the currently discussed projects. In particular, Herrero and Xu et al. (2017) questioned the possibility for gains from the Euro-Asia corridors for most of the local communities and companies. Similarly, de Soyres et al. (de Soyres et al. 2018; de Soyres 
et al. 2019) - applying a quantitative trade model aiming at quantifying the impact of BRI projects on GDP, welfare, and trade flows - highlighted that BRI transport corridors could generate overall benefits on the aggregate of the regions involved but there might be high disparities in terms of net advantages, depending on local conditions as well as on the specificities of different funding schemes. Thus, the still blurry picture of actual projects included in the BRI and the (mainly) political - rather than purely operational - nature of most of the projects make paramount to better understand market effects of main logistics projects (i.e. market competition, service reshuffling), also in connection with existing solutions or on-going projects.

\section{The BRI and the med}

As mentioned above, the BRI strategy has been developed mainly through discontinuous and independent investments often linked together in subsequent phases. This is the example followed, for instance, in the Central Asia Corridor, in which investments on the port sector have been followed by related investments in the rail and road sectors as well, but only in later stages. A similar approach is characterizing the BRI strategy in the European macro-region as well. In fact, rail services started to be operated even before the promotion of the first OBOR initiative (i.e. 2011), the Piraeus and other planned port investments from 2016, and the infrastructure investments agreed with main Central and Eastern Economies (CEE) from 2015 (among which the rail infrastructure between Piraeus and Budapest represents the main investment). While all these strategies might have been considered separately, all together they will heavily affect the future European logistics industry, with the Mediterranean area that might be the most affected one due to its pivotal role in connecting Europe with the Far East.

\section{The euro-Asia rail network}

Concerning the rail services, the current promoted services connect all main Chinese industrial cities with strategic location in Eastern and Central Europe, all of them being defined in the BRI official documents as the Euro-Asia landbridge corridor. From a logistic point of view, most of the services are currently planned to run on an updated infrastructure that pass through several Asian countries (e.g. Kazakhstan, Iran). This corridor has been under development to overcome the Russian railway route (that needs to be updated and it is characterized by a different gauge) and it is meant to serve as backbone to a wider Asian network (e.g. the Pakistan Economic Corridor partially lies on the same infrastructure). Among the main rail destinations, there are all the main Central (e.g. Germany) and Eastern (e.g. Poland, Baltic countries, Hungary, Czech Republic) countries, allowing cargos the reach Central Europe (i.e. the most relevant markets), bypassing the (slow) maritime routes. While the service started as exceptional solution, it is currently registering growing volumes that are also not related to the high value goods that were characterising first services. As described by $\mathrm{Li}$ et al. (2018b) current rail services are competitive in respect to the maritime service for a variety of potential cargo that needs reliable and rapid transport solutions. Moreover, while in the past train connections between China and Europe were mainly organised thanks to (public) BRI related subsidies, starting from 2015 a more balanced trade has occurred, making such services more profitable and then even more sustainable in the 
long run. This profitability though is highly related to the capability of attracting a growing volume of cargo. On this respect, Yang et al. (2018b) seem to question the possibility for this form of landbridge to be successful given that market operators still prefer the traditional maritime routes. In order to cope with this risk, BRI is planning to intervene in several ways, mainly either through international trade agreements (as those promoted with the CEE organisation) or incorporating currently EuroAsia rail services within other intermodal solutions, as suggested by Yang et al. (2018a) for the optimised COSCO network.

\section{COSCO strategy and the port of Piraeus}

The COSCO full acquisition of Piraeus Port - through a capital investment in the related Port Authority - occurred in 2016, after a decade of exclusive operation in one of the port terminals. The abovementioned operation is today considered as one of the most significant BRI investments worldwide and the biggest in Europe (e.g. Le Corre 2018; Mathews 2017). The overall investment value is estimated to be around $8 \mathrm{bln}$ USD, with already committed investment of about $500 \mathrm{mln}$ USD. At the end of the expansion plan, port of Piraeus will become one of the biggest Mediterranean hubs for container, with an expected capacity of 3.7 million TEU (against a volume of 450,000 TEU in 2017). Most of the containers will be not only destined to the Greek market but will be also transhipped in neighbouring countries, making Piraeus the main hub of the East Med.

For promoting the role of Piraeus, after the 2016 acquisition, COSCO reshuffled its services, using the Greek port as a pivotal node for all its vessels passing through the Mediterranean area. Moreover, given the agreement signed in 2016 by COSCO to form the "Ocean Alliance" in order to manage main Asia-Europe services together with CMA-CGM, Evergreen, and OOCL (now part of the COSCO group), all ports managed by the companies involved in the agreement received particular attention in the routing planning. For this reason, when the common routing plans for 2017 became public, Piraeus was used as Mediterranean hub for 4 out of 11 services connecting Asia and Europe (CMA-CGM 2018). Moreover, when in spring 2018 "The Alliance" and "Ocean Alliance" decided to cooperate for some of the offered services, Piraeus was included as pivotal port for both services in Europe-Asia and Med-Americas, despite the original absence from the routing between the latter region. This fact demonstrates the growing importance of the Greek port within the COSCO promoted network.

The strategic location of Piraeus makes the port not only a competitive logistics node for container shipping but for other markets as well. Given the diversified business of COSCO (e.g. bulk, ro-ro), the Chinese company is planning to transform the Greek port in its main hub for all its main trades from Asia to Europe, counting on the possibility to develop efficient services in all the maritime sectors.

The COSCO Shipping Port (CSP) company is the COSCO division for managing port operations, Currently CSP owns - at least partially - several terminals, mainly located in Far East Asia. Since the mid '00s, COSCO started to develop its worldwide network, not only investing in the Piraeus port but trying to enjoy multiple network economies. From a European perspective, CSP operations have, for instance, recently focused on the Zeebrugge port (Belgium) as well as with minority shares in both Rotterdam (The 
Netherlands) and Antwerp (Belgium). Within the Mediterranean area, while Piraeus is planned to be the main hub, other investments are currently planned. In 2017, CSP bought Noatum Ports, starting the management of a container terminal in Valencia (and Bilbao). Moreover, it currently holds minority shares in the Turkish port of Kumport (i.e., a potential end-point for the EuroAsia corridor) and in the Suez Canal Terminal (i.e., in a key port for entering the Med market).

Interestingly, in autumn 2016, CSP bought 40\% ownership of a new container terminal in Savona (Italy) with an expected capacity of 900,000 TEU. The terminal of Savona is of particular interest since the main shareholders is APM Terminals, theoretically a competitor in both the terminal and the shipping sector (being controlled by APM Maersk that belongs to a third alliance as well). Eventually, at the beginning of the Initiative COSCO was interested in developing a hub in the North Adriatic Sea, exploiting some of the investment plans introduced by the Venice Port Authority (Costa et al. 2020). Such interest has been partially confirmed (switching from Venice to Trieste), during the visit of President Xi in Italy in Spring 2019, with Trieste preferred to Venice also because of its better infrastructural links with the Central and Eastern European markets.

Together with the COSCO strategy, other investments included in the BRI might soon shape the future of the maritime sector within the Mediterranean basin. China Merchants Ports, for instance, currently holds shares in the biggest French ports (i.e., Marseille and Le Havre) as well as in the Mediterranean hub of Marsaxlokk (Malta), demonstrating the wide range of investments of associated BRI partners. The current investments will allow $\mathrm{COSCO}$ to easily operate over main trade routes, concentrating intercontinental traffic in its hub port - also in connection with the role of the operators within the Ocean Alliance - and then redirecting them to the final destinations, thanks to a future network of feeder ports in both West and East Med. The so-built network will probably assure a competitive advantage to the Chinese company in respect with not allied competitors, but it might also affect the port market as well, given the potential impact on transhipment flows (e.g. Marsaxlokk, Gioia Tauro, Port Said) in both sides of the Med basin.

\section{International agreements and future transport network}

In terms of transport corridors, European countries have experienced a unique supranational investment strategy within the Trans-European Transport Network (TEN-T) policy. Nevertheless, while most of these investments were thought to assure regional cohesion and accessibility, the BRI strategy is partially developing complementary projects aiming at interconnecting EuroAsia rail services with the Maritime Silk Road strategy. The biggest example is the China-CEE rail project for a high speed-high capacity rail connection between Athens and Budapest (passing through Serbia) that is planned to connect the Port of Piraeus to all major European markets through fast and reliable rail services.

The original project (agreed in 2015) was quite ambitious with the completion of the first part of the $1000 \mathrm{~km}$ corridor within a few years (i.e. Belgrade-Budapest), nevertheless construction works only started around the end of 2017 with an expected delivery date set for 2020. While current released technical details reduce the ambitions of the 
project (e.g. maximum speed down from the expected $250 \mathrm{~km} / \mathrm{h}$ to $160 \mathrm{~km} / \mathrm{h}$ ), the corridor will allow operators to have dedicated connections between several landlocked countries and one of the main Med ports, basically generating a definitive competitive advantage. The agreement of the rail construction, while boosted relations between China and CEE, generated several negative reactions in different European countries, given the potential negative effects of such foreign management on an internal EU trade. Moreover, the agreed project is partially in contrast with the Pan-European Corridor (project 2) of the TEN-T, generating overlaps with the EU transport planning and potential concerns about possible overcapacity issues. This fact led to the discussion of an "Investment screening regulation" aiming at preventing foreign investment in strategic European sectors (e.g. Costa et al. 2020). The approval of such mechanism happened in Spring 2019 (being effective starting from October 2020) with the potential of heavily affect the future BRI projects within the EU, reducing the spread of the Initiative within the European markets. This was also one of the main discussed issues during the visit of President $\mathrm{Xi}$ in Europe, trying to boost the BRI as complementary strategy, not in competition with the TEN-T projects.

\section{The effects of BRI on med ports}

Despite the small amount of literature addressing the effects of the BRI on the European transport sector, it is obvious that the several on-going projects will heavily affect the logistics solutions as well as the competition within the maritime sector. As discussed above, the only main maritime node currently included in the BRI strategy has already secured a pivotal role within the European-Asia trade lines and an important role in other intercontinental routes. The presence of COSCO in other European ports as well as the potential increase in connectivity of Piraeus through other rail and maritime solutions will probably grant a decisive competitive advantage for COSCO, with a cascading effect on other competing ports. As an example of such impact, it is worth noticing that in the last 5 years the connectivity of the port of Piraeus - calculated through the Port Liner connectivity Index (Unctad 2020) - has grown of $50 \%$ becoming the highest among the Mediterranean hubs while it was one of the lowest at the beginning of the BRI era.

In order to answer to such market concentration, some of the competing companies are also trying to increase their presence in different logistics activities (e.g. APM Maersk) but the possibility for COSCO to be "naturally" included in the BRI strategy assures a leading role in the land transport planning as well. Currently, this latter element seems to generate the main competitive disparity.

While from a market point of view, there is no possibility to intervene, EU authorities - as well as several national associations (e.g. TradeWinds 2018) - are currently promoting a series of political interventions, in order to limit the potential market distortions. On this regards, Yang et al. (2018a) offer an interesting simulation outcome: whenever rail and maritime services from China to Europe are run in coordination, an optimal routing system can be offered at present level of service, enlarging both the maritime operator network and maximising the load factor for the vessels, thus positively impacting on the two main competition elements. The abovementioned research results underline how the BRI overall could positively affect the competition within the 
Med basin at current stage, even without introducing the use of further feeder ports that are currently under discussion or development (i.e., Savona and Trieste). Nevertheless, the lack of coordination in developing further capacity - as well as the "triangulation" in providing alternative logistics corridors that target the same markets - might generate overcapacity. Such scenario might represent an advantage only for those market players capable of providing alternative services on most of such extended network, therefore exploiting such investment both as network economies and potential market barriers.

While the BRI might generate positive advantages for reaching key regions in both Europe and Asia, the situation mentioned above might generate distorting competitive situations for local (European) companies if investments (and services) will be not substantially regulated in order to prevent unfair competitive advantages. Similarly, whenever BRI and TEN-T overlaps, some kind of coordination seems necessary in order to avoid an oversupply of infrastructure capacity that could mine the profitability of the investments (thus generating social losses).

Table 3 sums up main insights coming from the considerations developed above. While the main strengths of BRI within the Mediterranean region seems to be linked to the current investment levels and with the already established network that can assure positive benefits for the served communities, these elements might also be seen as anticompetitive, generating extra-costs in the long run. A good example might be the extended port network developed by $\mathrm{COSCO}$ and the shipping market concentration that might create specific advantages due to network economies and a better capacity utilization. Such elements are currently under scrutiny by European governments and could create major frictions.

Looking with a perspective view, BRI opportunities for Med port and logistics stakeholders might be plenty and they are mainly connected to the possibility to have coordinated efforts with TEN-T projects, avoiding overcapacity and potential competitive advantages only for some market players, just using the two policies to increase accessibility for new local markets as well as to rationalise and boost investments in the port and transport sector.

\section{Conclusive remarks}

The current paper discussed the Belt and Road Initiative, highlighting current trends in the discussion of the project. While most of the currently published papers are mainly

Table $3 \mathrm{BRI}$ assessment within the Med Basin

\begin{tabular}{ll}
\hline Strengths & Weaknesses \\
• Local impact & $\cdot$ Contrast with EU institutions \\
• International view & $\cdot$ Impact inequalities \\
- Current investment level & $\cdot$ Possible anticompetitive behaviour \\
- Already established network & $\cdot$ Oversupply of infrastructure \\
Opportunities & Threats \\
• Complementarities with TEN-T & $\cdot$ Political barriers \\
- Access to new markets & $\cdot$ Market distortions \\
- Diversification of transport services & $\cdot$ Public debt of receiving countries \\
\hline
\end{tabular}

Source: Authors' elaboration, 2020 
focusing on the political debate around the BRI strategy, only a minority of studies discusses the transport implications of planned investments. In fact, while the estimated amount of investment has the capability of reshaping most of the current transport infrastructure in both Asia and Europe, the slow progress in actually developing the planned infrastructure reduced the interest of academia in looking at specific transport aspects. Overall, all the BRI related paper focusing on transport deal with either specific case studies or with the optimisation of future corridors, while no papers focus on the potential effects of BRI on the port competition level of the Mediterranean area. This lack of interest is quite unexpected given the several projects currently under discussion as well as the main development of several Mediterranean ports, directly or indirectly connected to the BRI strategy (e.g. COSCO investments in Piraeus). Moreover, most European countries are facing modifications at both sea and land side, thanks to the development of new rail services from China and to dedicated infrastructure investments that are generating competition with the Trans-European Transport Network projects. The abovementioned scenario increases the need for market studies, in order to highlight threats and opportunities for main market operators as well as for potential impacts on local communities.

The current study has the aim of being a first exploratory discussion, future development will include surveys and interviews to main operators, with the aim of quantifying expecting impacts of BRI related investments that might change the Mediterranean port industry. Despite this, the current research highlighted how current BRI related projects might indeed have a huge impact in terms of port competition in the Mediterranean area with current major investments that are all linked to the BRI main actors. Moreover, the simultaneous development of novel logistics corridors that might be used as complementary solution might multiply the impact of BRI on European logistics. Such impacts might be either positive or negative depending on relevant regulation and on the level of coordination between European initiatives (e.g. TEN-T) and the BRI promoted projects.

\section{Abbreviations}

APM Maersk: A.P. Moller Maersk; BRI: Belt and Road Initiative; CEE: Central Eastern Europe; Cma-Cgm: Compagnie Maritime d'Affrètement - Compagnie Générale Maritime; COSCO: China Ocean Shipping Company; CSP: CosCo Shipping Ports; EBRD: European Bank for Reconstruction and Development; GDP: Gross Domestic Product; M\&A: Merger and Acquisitions; OBOR: One Belt, One Road; OOCL: Orient Overseas Container Line; TEN-T: TransEuropean Network-Transport; USD: United States Dollar

Acknowledgements

Authors are grateful to the attendants of the SIGA2-WCTR2019 conference for all valuable comments given during the presentation of a preliminary version of current research.

Authors' contributions

All authors have contributed to the writing of the paper. All authors have read and approved the final manuscript.

Funding

Authors have not received any funding for this research. 
Received: 9 August 2019 Accepted: 4 June 2020

Published online: 10 July 2020

\section{References}

Bao X. (2018). Urban rail transit present situation and future development trends in China: overall analysis based on National Policies and strategic plans in 2016-2020. Urban rail Transit4

Bekturganov NS, Bolaev AV (2017) The Eurasia canal as a factor of economic prosperity for the Caspian region. Geogr Environ Sustainability 10:34-43

Calabrese J (2017) China's "one belt, one road" (OBOR) initiative: envisioning Iran's role. In: China's Presence in the Middle East: The Implications of the One Belt, One Road Initiative, pp 174-191

Chen Z (2017) The influence of 3D printing on global container multimodal transport system. Complexity 2017, p. 1-19

Cheng L (2016) Three questions on China's "belt and road initiative". China Econ Rev 40:309-313

Chhetri P, Nkhoma M, Peszynski K, Chhetri A, Lee PT-W (2018) Global logistics city concept: a cluster-led strategy under the belt and road initiative. Marit Policy Manag 45:319-335

Chia SY (2016) ASEAN economic integration and physical connectivity. Asian Econ Papers 15:198-215

Choi K-S, Chen X-Q (2018) Study on the mediating effects of changing logistics environment in Korea and China on attitude and choice intention of shippers on the train ferry. J Korean Soc Railway 21:118-129

Clarkson-SIN (2019). sin.clarkson.net

CMA-CGM (2018). Ocean Alliance routing system, https:/www.cma-cgm.com/news/1361/ocean-alliance-sets-out-network

Costa P, Haralambides H, Roson R (2020) From trans European (ten-T) to trans global (Twn-T) transport infrastructure networks. A conceptual framework. In: Cerniglia F, Saraceno F (eds) European public investment outlook, open book publishers, Cambridge forthcoming

Dave B, Kobayashi Y (2018) China's silk road economic belt initiative in Central Asia: economic and security implications. Asia Europe J 16:267-281

de Soyres F, Mulabdic A, Murray S, Rocha N, Ruta M (2018) How much will the belt and road initiative reduce trade costs?, World Bank policy research working paper, vol 8614

de Soyres F, Mulabdic A, Ruta M (2019) Common transport infrastructure: a quantitative model and estimates from the belt and road initiative, World Bank policy research working paper, vol 8801

Ding H.-C., Lian M.-R., Chen X.-Y., Liu J.-M., Zhong Z.-C., Zhang Y.-F., Zhou M.-Y. (2018). Research on the correlation of port logistics and regional economic growth base on gray relational analysis method. Concurrency Computation

Drewry (2018) Container forecast, quarter 2. Drewry Maritime Research, London

Du Q, Shi X, Bai L, Gao S (2018) Performance analysis of container yard based on batch service queueing system. J Interdiscip Math 21:747-760

EBRD (2018). https://www.ebrd.com/what-we-do/belt-and-road/overview.html

Fallon T (2015) The new silk road: xi Jinping's grand strategy for Eurasia. Am Foreign Policy Interests 37:140-147

Ferdinand P (2016) Westward ho- - the China dream and 'one belt, one road': Chinese foreign policy under xi Jinping. Int Aff 92:941-957

Ferrari C, Bottasso A, Conti M, Tei A (2018) Economic role of transport infrastructure. Elsevier, Amsterdam

Heng Z, Yip TL (2018) Impacts of Kra Canal and its toll structures on tanker traffic. Marit Policy Manag 45:125-139

Herrero AG, Xu J (2017) China's belt and road initiative: can Europe expect trade gains? China World Econ 25:84-99

Hou J (2017a) Dynamic berth allocation problem with two types of shore power for containership based on rolling horizon strategy 2017 2nd IEEE international conference on intelligent transportation engineering, vol 2017. Singapore: ICITE, pp $144-149$

Hou J (2017b) Intermodal transport problem of container terminal in emission control area. In: Proceedings of 2017 IEEE 3rd information technology and mechatronics engineering conference. ITOEC 20172017-January231237

Hou J (2018) Dynamic multi-objective optimization problem of container intermodal transport: an empirical analysis on the belt and road initiative of China. Lect Notes Electrical Eng 483:679-688

Huang Y (2016) Understanding China's Belt \& Road Initiative: motivation, framework and assessment. China Econ Rev 40:314321

Huasheng Z (2016) Afghanistan and China's new neighbourhood diplomacy. Int Aff 92:891-908

Ismailov E, Papava V (2018) Caucasian tandem and the belt and road initiative. Central Asia Caucasus 19:7-17

Ji S, Sun Q (2017) Low-carbon planning and design in B \& R logistics service: a case study of an E-commerce big data platform in China. Sustainability (Switzerland) 9:27

Jiang Y, Sheu J-B, Peng Z, Yu B (2018) Hinterland patterns of China railway (CR) express in China under the belt and road initiative: a preliminary analysis. Transportation Res Part E 119:189-201

Kuzmicz KA, Pesch E (2018) Approaches to empty container repositioning problems in the context of Eurasian intermodal transportation, omega (United Kingdom)

Lapidus BM, Misharin AS (2018) Cargo-and-passenger high-speed railway "TransEurasia": a unique megaproject. Econ Region 14:339-352

Lau Y-Y, Tam K-C, Ng AKY, Fu X, Jing Z, Feng J (2018) Effects of the 'belt and road' initiative on the wine import logistics of China. Maritime Policy Manag 45:403-417

Lávut AA (2018) Latin American region (Lac'S) participation in China'S belt and road initiative [La Iniciativa China "La Franja y la ruta" Y los Países De América Latina Y El Caribe]. Iberoamerica (Russian Federation) 20:184-267

Le Corre P (2018) Chinese Investments in European Countries: experiences and lessons for the "belt and road" initiative. In: Mayer M (ed) Rethinking the silk road. Palgrave Macmillan, Singapore

Li KX, Jin M, Shi W (2018a) Diversification as an energy importing strategy for China under the belt and road initiative. Int J Shipping Transport Logistics 10:335-354

Li T, Liu J, Wang L, Zhu H, Yu L (2017) Spatial differences in international investment in hotels and its driving factors in China. Dili Xuebao/Acta Geographica Sinica 72:1904-1919

Li Y, Bolton K, Westphal T (2018b) The effect of the new silk road railways on aggregate trade volumes between China and Europe. J Chin Econ Bus Stud 16:275-292 
Li Y, Schmerer H-J (2017) Trade and the new silk road: opportunities, challenges, and solutions. J Chinese Econ Bus Stud 15: 205-213

Lim S-W, Suthiwartnarueput K, Abareshi A, Lee PT-W, Duval Y (2017) Key factors in developing transit trade corridors in Northeast Asia. J Korea Trade 21:191-207

Liu J, Zhang R, Liu B (2018) Transportation mode selection and supply chain channel coordination of products with price depended on freshness. Jisuanji Jicheng Zhizao Xitong/Computer Integrated Manufacturing Systems, CIMS 24:272-280

Malle S (2017) Russia and China in the 21st century. Moving towards cooperative behaviour. J Eurasian Stud 8:136-150

Mathews J (2017) China's takeover of the port of Piraeus in Greece: blowback for Europe. Asia Pac J 15:1-5

Mednikarov B, Admiral F, Lutzkanova S, Yotsov I (2017) Overview on some political and economic aspects for Bulgaria in the context of the new Eurasian economic corridors. 18th annual general assembly of the International Association of Maritime Universities - global perspectives in MET: towards sustainable. Green Integr Marit Transport 20171:426-438

Midoro R, Pitto A (2000) A critical evaluation of strategic alliances in liner shipping. Marit Policy Manage 27:31-40

Mikheev W, Lukonin SA, Jeh SH (2015) Multivariance: xi Jinping' big strategic answer. World Econ Int Relat 59:5-14

Napasirth P, Napasirth V (2018) Current situation and future prospects for beef production in Lao People's Democratic Republic - a review. Asian Australas J Anim Sci 31:961-967

Nazarko J, Czerewacz-Filipowicz K, Kuźmicz KA (2017) Comparative analysis of the eastern European countries as participants of the new silk road. J Bus Econ Manag 18:1212-1227

Nežerenko O, Koppel O (2017) The Baltic Sea macro-regional transport cluster as an element of the silk road Economic Belt. Croatian Int Relat Rev 23:77-95

Ng A, Jiang C, Li X, O'Connor K, Lee P (2018) A conceptual overview on government initiatives and the transformation of transport and regional systems. J Transp Geogr 71:199-203

Notteboom TE, Parola F, Satta G, Pallis AA (2017) The relationship between port choice and terminal involvement of alliance members in container shipping. J Transp Geogr 64:158-173

Pelagidis T, Haralambides H (2019) The belt and road initiative (BRI) and China's European ambitions. World Econ 20: $221-232$

Psaraftis H, Pallis A (2012) Concession of the Piraeus container terminal: turbulent times and the quest for competitiveness. Marit Policy Manag 39:27-43

Qiu X, Wong EYC, Lam JSL (2018) Evaluating economic and environmental value of liner vessel sharing along the maritime silk road. Marit Policy Manag 45:336-350

Rozov NS (2018) China's one belt, one road initiative and the paradigms of historical macrosociology. Novosibirsk State Pedagogical Univ Bull 8:173-188

Saha RC (2018) Regional cooperation in port development to bolster maritime logistics Services in South Asia. In: International conference on transportation and development 2018: traffic and freight operations and rail and public transit - selected papers from the international conference on transportation and development, 2018, pp $142-155$

Sharif N, Hyder SI (2017) An opportunity to attract local investment. In: CPEC (ed) Proceedings of the 29th international business information management association conference - education excellence and innovation management through vision 2020: from regional development sustainability to global economic growth, pp 607-614

Sheu JB, Kundu T (2018) Forecasting time-varying logistics distribution flows in the one belt-one road strategic context. Transport Res Part E 117:5-22

Sterling SE, Liu B (2018) Chinese sociocultural perspectives and creativity: design practices in the public transport sector. In: Lecture notes in computer science (including subseries lecture notes in artificial intelligence and lecture notes in bioinformatics), 10912 LNCS, pp 225-234

Stopford M. (2009). Maritime Economics, 3rd Edition, Routeldge: London (UK)

Suocheng D, Kolosov V, Yu L, Zehong L, Fujia L, Minyan Z, Guangyi S, Huilu Y, Hao C, Peng G (2017) Green development modes of the belt and road. Geography Environ Sustain 10:53-69

To W.M, Lee PKC (2018) GHG emissions from China's international sea freight transport: a review and the future trend. Int J Shipping Transport Logistics 10:455-467

Tradewinds (2018). TradeWinds - The Global shipping news source, www.tradewindsnews.com

Unctad (2020). Port liner shipping connectivity Index, UnctadStat, https:/unctadstat.unctad.org/

Wang J, Jiao J, Ma L (2018) An organizational model and border port hinterlands for the China-Europe railway express. J Geogr Sci 28:1275-1287

Wang JJ, YAU S (2018) Case studies on transport infrastructure projects in belt and road initiative: an actor network theory perspective. J Transp Geogr 71:213-223

Weihai L (2017) A security model and legal guarantee for Chinese maritime shipping: as exemplified in the response to piracy along the 21st century maritime silk road. Soc Sci China 38:46-65

Xu Q, Shen L, Jiang Y, Jin Z (2017) Multimodal transport routing problem considering transshipment and accessibility: the case of the 'One belt one Road' initiative. In: 2017 4th international conference on transportation information and safety, ICTIS 2017 - proceedings, pp 936-942

Yang D, Jiang L, Ng AKY (2018b) One belt one road, but several routes: a case study of new emerging trade corridors connecting the Far East to Europe. Transp Res A Policy Pract 117:190-204

Yang D, Pan K, Wang S (2018a) On service network improvement for shipping lines under the one belt one road initiative of China. Transp Res E 117:82-95

Yu Y, Chang Y-C (2018) The 'one belt one road' initiative and its impact on shipping law in China. Mar Policy 87:291-294

Zeng Q, Wang GWY, Qu C, Li KX (2018) Impact of the Carat Canal on the evolution of hub ports under China's belt and road initiative. Transport Res Part E 117:96-107

Zhang G-W (2016b) Multimodal transport service system of the belt and road. Jiaotong Yunshu Xitong Gongcheng Yu Xinxi $16: 1-13$ 
Zhang H (2018) Countermeasures for the development of the international multimodal transportation under the construction of the belt and road. In: CICTP 2018: intelligence, connectivity, and mobility - proceedings of the 18th COTA international conference of transportation professionals, pp 2673-2677

Zhang M-T (2016a) Research on the railway corridor construction for Liaoning province assimilated into "the belt and road initiative". J Railway Eng Soc 33:14-17

Zhu Y, Vadim F (2018) Comparative study of international carriage of goods by railway between CIM and SMGS. Front Law China 13:115-136

\section{Publisher's Note}

Springer Nature remains neutral with regard to jurisdictional claims in published maps and institutional affiliations.

Submit your manuscript to a SpringerOpen ${ }^{\circ}$ journal and benefit from:

- Convenient online submission

- Rigorous peer review

- Open access: articles freely available online

- High visibility within the field

- Retaining the copyright to your article

Submit your next manuscript at $\boldsymbol{\nabla}$ springeropen.com 